\title{
Erratum to: New research on the cultural history of the useful plant Linum usitatissimum L. (flax), a resource for food and textiles for 8,000 years
}

\author{
Sabine Karg
}

Published online: 12 November 2011

(C) Springer-Verlag 2011

\section{Erratum to: Veget Hist Archaeobot (2011) 20:507-508 DOI 10.1007/s00334-011-0326-y}

Unfortunately during production the last paragraph of the Editorial by $\mathrm{S}$. Karg was deleted, and it is now given below.

In 2009 and 2010 the Danish Research Council financed the organization of two workshops that were organized in Denmark (Karg 2009, 2010). Participants of these international meetings comprised prehistoric and classical archaeologists, historians, textile researchers and natural scientists such as botanists, molecular geneticists, geologists and physicists from Scandinavia, the United Kingdom, Germany, Belgium, France, Switzerland, Estonia, Greece, Israel and the United States. The fruitful discussions during these workshops have resulted in articles for this special issue of Vegetation History and Archaeobotany which represent the latest results in archaeobotany and archaeology concerning many aspects of the cultural history of flax in the course of time and in different geographical regions.

The online version of the original article can be found under doi:10.1007/s00334-011-0326-y.

S. Karg $(\bowtie)$

SAXO Institute, Archaeology, University of Copenhagen,

2300 Copenhagen S, Denmark

e-mail: karg@hum.ku.dk 